\section{environmental conditions along a W-E transect through northern Poland}

\author{
NORPOLAR Workshop, Gdańsk, Poland, 3-8 September 2010
}

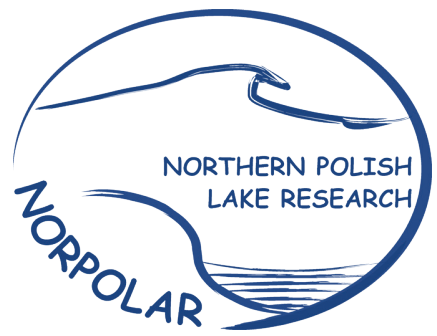

Wojciech Tylmann ${ }^{1}$ and BeRnd ZolitschKA ${ }^{2}$

'Department of Geomorphology and Quaternary Geology, University of Gdansk, Poland; geowt@ug.edu.pl ${ }^{2}$ GEOPOLAR, University of Bremen, Germany

The project "Northern Polish Lake Research" (NORPOLAR) is a Polish-German joint research program based on a bilateral cooperation between the Department of Geomorphology and Quaternary Geology (Institute of Geography, University of Gdańsk) and GEOPOLAR (Institute of Geography, University of Bremen). In this framework, interdisciplinary research on annually laminated sediments at four lake sites in Northern Poland has been carried out, aiming at: (1) establishing absolute and multiple-dated chronologies for all four records, (2) linking paleodata with instrumental and monitoring data to improve our understanding of pathways from forcing factors via processes to proxy records, (3) providing high-resolution data sets of paleoredox conditions, paleoproductivity, lake water balance, lacustrine carbon cycling and soil erosion, and (4) providing regional data sets of reconstructed climate parameters to be used in combination with the output of downscaled or regional climate models.

Within NORPOLAR we also address one of the major aims of the former ESF-funded European Lake Drilling Programme (ELDP), i.e., to analyze past climate and environmental variability along transects throughout Europe. The NORPOLAR lakes are located along a W-E transect covering the entire latitudinal extension of Poland from 15 to $23^{\circ} \mathrm{E}$ (Fig. 1) with a distinct maritime to continental climatic trend, i.e., a decrease in mean annual temperature from 8.5 to $6.0^{\circ} \mathrm{C}$ from West to East.

The NORPOLAR Workshop was organized by Wojciech Tylmann and Małgorzata Kinder. It teamed 23 participants from Poland, Germany and Switzerland (Fig. 1). The aims of this workshop were twofold: (1) To familiarize all project participants with the up-to-date state of scientific results, and (2) To develop a strategy for future research activities. The workshop included invited lectures, oral presentations by all project members and a forum for discussion. Five oral sessions were organized during two days of intense work. The first day was devoted

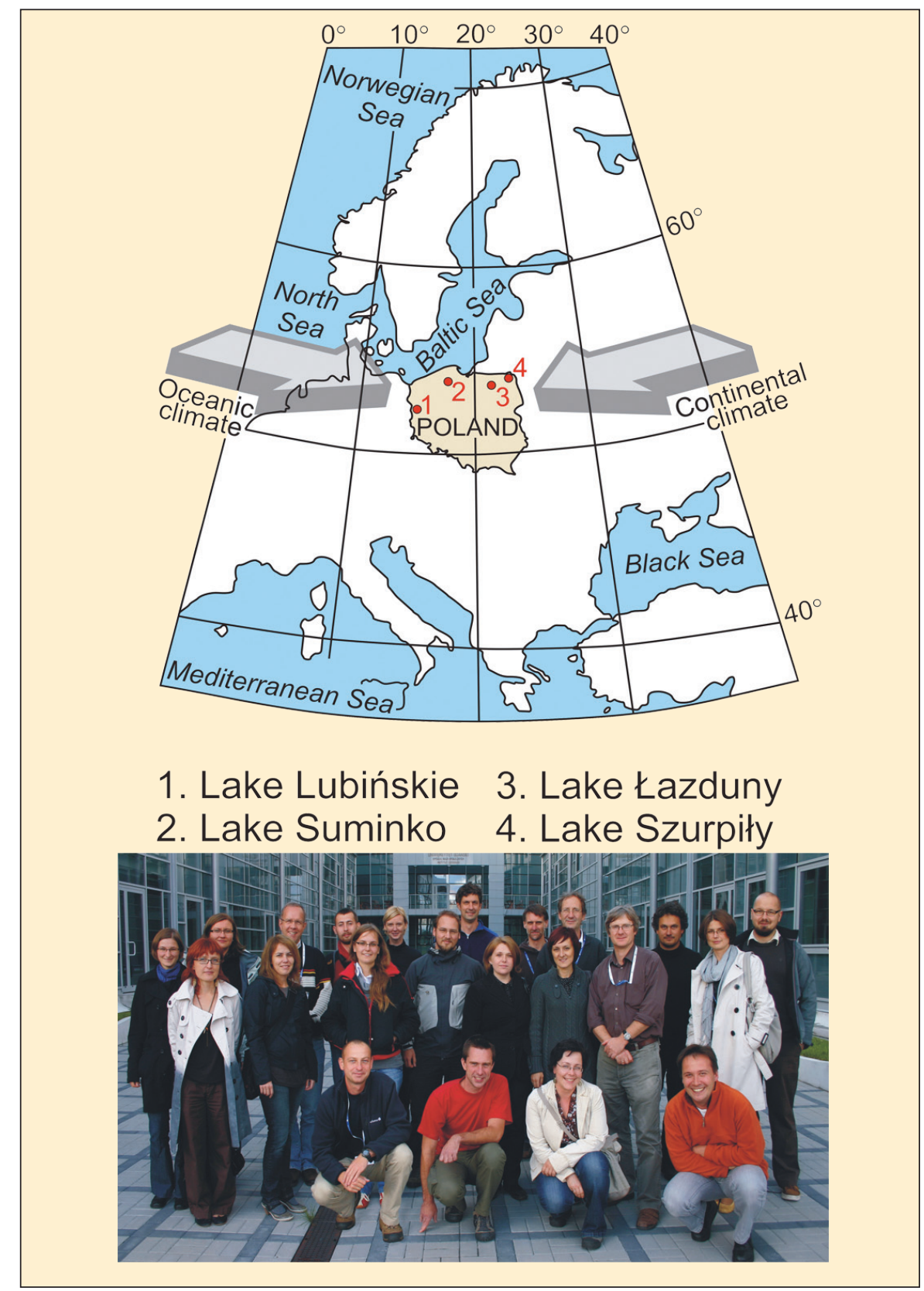

Figure 1. Locations of NORPOLAR lake sites and participants of the NORPOLAR Workshop in front of the Faculty of Social Sciences building at Gdańsk University to a general introduction, the lithology of varved sediment records and dating issues, while the second day focused on biological proxies.

We started with excellent talks on the nature of varves and the current state of seasonal climate reconstruction from varved sediments presented by Achim Brauer (German Research Centre for Geosciences, Potsdam) and Christian Kamenik
(University of Bern, Switzerland), respectively. The following talks explained the general idea of the project, reported on fieldwork, core correlation as well as on sub-sampling strategies, and shed some light on issues related to chronological and geochemical data interpretation. During the second day three sessions dealt with pollen, diatom and cladocera analyses of the varved sediment records from 
four sites studied so far within NORPOLAR (Fig. 1).

The final discussion addressed future NORPOLAR research strategies. There was general consensus on the high potential of these sediment records, especially for high-resolution reconstructions of climatic and environmental variations during the last $3 \mathrm{ka}$ but also back to the early Holocene. Based on personal links established during the $1^{\text {st }}$ PAGES Varves Working Group Workshop (see: PAGES news, vol. 18(2)), NORPOLAR grew to become a trilateral research project, now also involv- ing Swiss scientists from the University of Bern.

The workshop ended with two field trips taking workshop participants to the largest active dune field in Europe (Słowiński National Park), to the Gdańsk University Marine Station on Hel peninsula, and to the cliff at Jastrzębia Góra, one of the few outcrops in Northern Poland with exposed Miocene clays and silts covered by Quaternary glacial sediments. Here the observing eyes of the varvologists (Quaternary scientists working with varved sediments) recognized glacial varves in a small section that has most likely been relocated as a frozen block by the glacier. These two days filled with plenty of atmosphere were great for continuative and in-depth scientific discussions related to NORPOLAR.

NORPOLAR was jointly sponsored by the Polish Ministry of Science and Higher Education and the German Research Foundation (DFG). More information about NORPOLAR is available at www.norpolar.ug.edu.pl.

\section{PMIP3 workshop}

\section{Paleoclimate Modelling}

\section{Kyoto, Japan, 6-10 December 2010}

\section{Andreas Schmittner ${ }^{1}$, A. Abe-Ouchi' ${ }^{2}$, P. Braconnot ${ }^{3}$, S.P. Harrison ${ }^{4}$ and B.L. Otto-Bliesner ${ }^{5}$ \\ ${ }^{1}$ College of Oceanic and Atmospheric Sciences, Oregon State University, Corvallis, USA; aschmitt@coas.oregonstate.edu}

${ }^{2}$ Atmosphere and Ocean Research Institute, University of Tokyo, Japan; ${ }^{2}$ Laboratory for Climate

and Environmental Sciences, Gif-sur-Yvette, France; ${ }^{4}$ Macquarie University, Sydney, Australia; ${ }^{5}$ Climate and Global Dynamics Division, National Center for Atmospheric Research, Boulder, USA

Past changes in Earth's climate, as evidenced by a myriad of paleo-environmental records, inform our understanding of the coupled climate system and can be used to evaluate models used for future projections. The Paleoclimate Modelling Intercomparison Project (PMIP; endorsed by WCRP, PAGES and INQUA/PALCOMM; Joussaume and Taylor, 1995) has taken on the important task of organizing and facilitating a systematic comparison of past climate simulations from different models and paleodata. This involves the definition of common experimental designs, running experiments for key time periods, and syntheses of data sets. Building on its successful work since the 1990s, PMIP, now in its third phase (PMIP3; Otto-Bliesner et al., 2009), remains close to future climate investigation, and has opened new research frontiers through investigation of additional time periods and transient simulations. More than 100 scientists from around the world contributed to this vibrant community effort at the recent workshop sponsored by the Japan Society of Promoting Science, the University of Tokyo and the Japan Agency for MarineEarth Science and Technology.

PMIP3 continues work on the Last Glacial Maximum (LGM, 21 ka ago) and the mid-Holocene (6 ka ago), and has begun work on the Last Millennium. These key time periods are now recommended as high priority (Tier 1 and 2) simulations in the Coupled Model Intercomparison Project Phase 5 (CMIP5; Taylor et al., 2009) using the same models that will be used for projections of future climate for the upcoming $5^{\text {th }}$ Assessment Report of the Intergovernmental Panel on Climate Change. This is a new and exciting development because paleoclimate simulations were previously done with different modelstypically coarser resolution-from those used for future simulations, interrupting

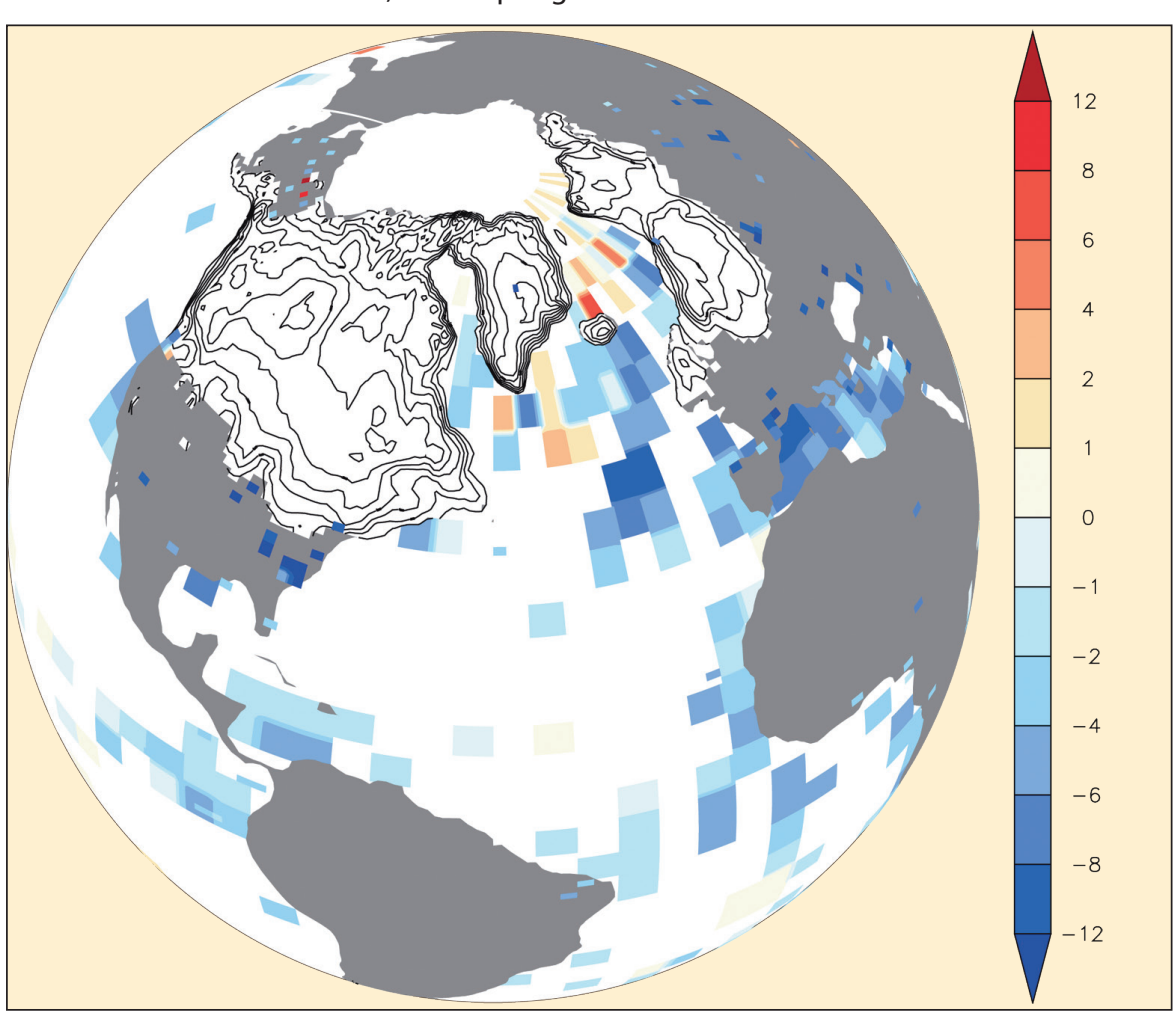

Figure 1: Reconstructions of northern hemisphere ice sheets (contour lines show 500 m elevation differences, available at http://pmip3.Isce.ipsl.fr) and surface temperature differences from modern (color scale in K) for the Last Glacial Maximum. Sea surface temperatures are from the Multiproxy Approach for the Reconstruction of the Glacial Ocean Surface project (MARGO; Waelbroeck et al., 2009), land surface air temperature reconstructions are based on pollen (Bartlein et al., 2010), with additional data from Shakun et al. (in preparation). These data, in combination with model simulations, provide unique constraints on climate sensitivity, confidently excluding high values (> 4.5 Kper doubling of $\left(\mathrm{O}_{2}\right.$ ) (Hargreaves et al. 2011, Schmittner et al., Yoshimori et al., submitted). the direct link between past and future. PMIP will also be assessing carbon-cycle modeling, through its daughter project PCMIP (PalaeoCarbon Modelling Intercomparison Project; Abe-Ouchi and Harrison, 2009), focusing on simulations of the LGM and the Last Millennium. 